\title{
Research on Influence Factors of Creativity Development of Applied Undergraduate
}

\author{
Xiangmin Ren, Kechao wang, Dexun Jiang, Qi Ran \\ School of software \\ Harbin University \\ Harbin, China \\ min0070@sina.com
}

\begin{abstract}
Creativity is one of the most core characteristics of talent, creativity development of students are top priorities for higher education. First, we introduce the importance of creativity development and definition briefly, investigate and study the current situation of applied undergraduate about creativity development education. Second, we analyze the basic data from papers and questionnaires of applied undergraduate, and conclude the important influence factors of creativity development of applied undergraduate based on knowledge mining technology. Third, we divide these factors into two types: external factors and internal factors, and analyze these factors one by one. These important factors have important guiding significance to the training methods, education and teaching of creativity development for undergraduate, especially applied undergraduate.
\end{abstract}

Keywords—applied undergraduate; talent training; creativity; influence factors

\section{INTRODUCTION}

It is pointed out that improve university's teaching level and innovation ability, and make some universities and a group of disciplines achieve or close to the world standards, build modern vocational education system, promote the integration of production and education, university-enterprise cooperation, optimize the layout of disciplines and majors, and talents training mechanism, encourage some universities to change into applied universities in "Central Committee of the Communist Party of China: Recommendations for the 13th Five-Year Plan for Economic and Social Development".

In the new international and domestic situation, China's industrial structure continues to optimize and upgrade, economic development engine is gradually changing from factor-driven, investment-driven to innovation-driven, put forward new quality requirements for the demand characteristics of labor force and talents in China. The meaning and characteristics of applied innovation talents fit in with the structure characteristics of talent demand in China.

Under the thinking of Premier Li Keqiang's "mass entrepreneurship and innovation", higher education is the main body and infrastructure of national innovation, so do applied universities. Applied university must improve student's professional abilities, cultivate student's creativity and employability, and explore the training mode of applied talents combining the actual situation of universities and the needs of local economic and social development. Applied undergraduate pay attention to not only training application ability and practical ability, but also training creativity development. Creativity development and enlightenment will be the important point of higher education also is the distinguishing feature of applied universities, is the key element of improving education level,

The development and Enlightenment of students' creativity will be the focus of building high-quality higher education, and also the key to highlight the characteristics of applied universities and improve the level of education and teaching, so as to meet the talent requirements of the development of the innovative country.

Applied talents are professional talents who can apply professional knowledge and skills to professional social practice[1], and master the basic knowledge and skills of social production and social life, mainly engage in front line production of professional talents. Modern society has a wide range of demand for this kind of talent, and applied talents occupy a large proportion in the entire talent needs. The talents of applied undergraduate should have: a profound knowledge of basic theory; a strong professional knowledge and practical ability; the ability of flexible application of knowledge and a certain creative ability; a wide range of knowledge and communication skills[2].

The creativity of applied talents is the ability to propose new inventions, new products, new technologies, and even new theories, and can make new improvements, innovations and breakthroughs in the existing products, technologies and theories.

Creativity comes from the Latin word "creave", which means foundations, creation, production and accomplishment. In 1950s, Guilford made a rapid development of research on creativity[3]. Amabile thinks creativity is not the ability of a few people[4]. Creativity is a capability that everyone has. It is not a special ability for a few special talents. Creativity comes from science, art, education, business and every aspect of life. Environment plays an important role in the formation and development of creativity. It can be seen that creativity is not a special ability for knowledge talents trained by research universities, and everyone is creative. Therefore, it is necessary to study the development of Applied Undergraduate Talents' creativity. 


\section{THE PRESENT SITUATION OF CREATIVE TRAINING FOR APPLIED UNDERGRADUATE TALENTS}

A. The content of teaching is obsolete, the course setting is backward, the frontier knowledge is lacking, and the coherence between courses is insufficient

The development of science is changing with each passing day, new technologies and tools are emerging. The old curriculum system and teaching content often cause students' knowledge structure to be divorced from the reality of discipline development, which is difficult to adapt to the requirements of enterprises and future work. There is still a certain gap between the teaching contents and the latest technologies. Teaching contents are rather old, which make the talents lack the frontier of knowledge and technology, and affect the development of creativity. At the same time, there is no strong correlation between courses, which causes the students do a slavish copy and follow the instructions to complete the experiment respectively.

\section{B. The teacher's innovation and enterprise experience are insufficient, and the teaching method is simple}

The teacher had finished teaching contents according to the teaching plan and other guidance documents, but may not be clear which technology is important, which technology has been outdated and is no longer in use in the actual production process in experiment teaching. The actual production experience of teachers is insufficient, which affects the development of students' creativity to some extent.

Classroom instruction is the main form, and knowledge is imparted by teachers in terms of teaching methods. The forcefeeding method ignores students' learning initiative and ignores the cultivation and excavation of students' creativity.

In addition, scores are most important and students' test scores are more concerned in terms of curriculum evaluation. However, these scores are difficult to present students' selflearning ability and creativity in learning process.

\section{Students' creative quality and creativity are not enough,} and creative consciousness and enthusiasm are not enough

All students have to complete the same experiment and understand every course in traditional teaching. This training mode can enable students to acquire more knowledge and enhance their professional skills, but they neglect their interest and specialty. Uniform training mode is lack of innovation. Nowadays, the division of labor in the production process is becoming more and more fine, the application field is more and more wide, and the professional features of the post are becoming stronger and stronger. We should explore new training methods, teach students in accordance with their aptitude, develop their strengths according to their interests and hobbies, and cultivate students in a targeted way, so as to fully mobilize their innovation and enthusiasm, and further enhance their creativity.

The teaching process of the university focuses on knowledge and skills, neglects the training of team cooperation ability. In fact, the quality of teamwork directly affects the exertion of creativity. In the process of university experimental teaching, it is often one person or two people to complete the experiment, which leads to the slow integration of team members when students began to work and develop creativity difficultly.

\section{Lack of innovation environment and practice}

Students' enthusiasm of participation in various academic competitions is not enough, and there is no strong concern and good environment. Even a lot of students who participate in teams and academic competitions may have quite good ideas, but they fail to put into action because they can't get the necessary technical support.

\section{INFLUENCE FACTORS OF CREATIVITY DEVELOPMENT OF APPLIED UNDERGRADUATE}

What are the specific factors that affect the development of students' creativity? Influence factors of the development of creativity are numberless. First, you need to find out important factors affecting the development of creativity, through statistical classification, and the importance of these influence factors of creativity development should be analyzed, so that the university can do teaching mechanism reform, curriculum system reform, and practice teaching reform based on these influence factors, in order to cultivate the student's innovative spirit and creativity. We can find out the influence factors of creativity development from relevant scientific research literature.

\section{A. Literature knowledge mining technology}

Literature knowledge mining technology refers to acquiring knowledge closely related to keywords from a large number of related research literatures based on predefined keywords. This technology is mainly based on the semantic similarity relation of Chinese words, the distance between Chinese texts, and the logical relationship between Chinese paper paragraphs, so as to measure the correlation degree between Chinese words, and finish the knowledge mining according to the keywords.

According to the basic keywords specified by the user, we get the cover keywords that are similar to the basic keywords from the matching list of Chinese semantic similar words. Based on the cover keywords we search the cover keywords from large quantities of scientific literatures, and find out the Chinese paragraph as the initial items of influence factors according to some words near the cover keywords and the paragraphs with cover keywords. The process of knowledge mining based on texts can be seen in Fig. 1.

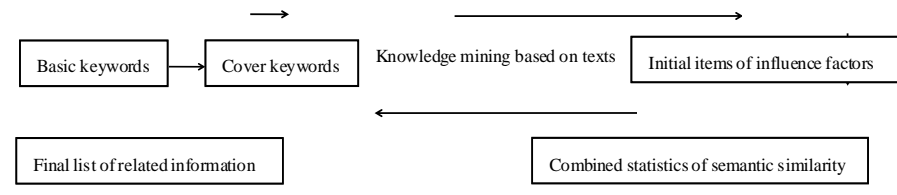

Fig. 1. The process of knowledge mining based on texts 


\section{B. The influence factors of creativity development based on knowledge mining technology}

We select applied undergraduate, talent training, creativity development, influence factors and so on as keywords according to knowledge mining technology as mentioned above. We divided into two types: external factors and internal factors. External factors include society influence; education influence, and surroundings influence, internal factors include intelligence influence, knowledge and skills influence, personality influence, and motivation influence and so on. We got the important influence factors of creativity development as follows:

TABLE I. THE IMPORTANT INFLUENCE FACTORS OF CREATIVITY DEVELOPMENT OF APPLIED UNDERGRADUATE

\begin{tabular}{|c|c|c|c|}
\hline \multicolumn{3}{|c|}{ Categories } & Contents \\
\hline \multirow{7}{*}{$\begin{array}{l}\text { External } \\
\text { factors }\end{array}$} & \multirow{3}{*}{ society } & culture & $\begin{array}{l}\text { sense of worth, social culture, } \\
\text { habits and customs, culture } \\
\text { quality }\end{array}$ \\
\hline & & $\begin{array}{l}\text { public } \\
\text { opinion }\end{array}$ & $\begin{array}{l}\text { general mood of society, social } \\
\text { order, open and transparent } \\
\text { information, honor incentives }\end{array}$ \\
\hline & & $\begin{array}{l}\text { personal } \\
\text { relations }\end{array}$ & $\begin{array}{l}\text { communicative ability, social } \\
\text { network relation, a harmonious } \\
\text { interpersonal relationship }\end{array}$ \\
\hline & \multirow[t]{2}{*}{ education } & $\begin{array}{l}\text { higher } \\
\text { education }\end{array}$ & $\begin{array}{l}\text { teaching idea, teaching } \\
\text { method, teaching management, } \\
\text { teacher management, } \\
\text { excitation mechanism, great } \\
\text { attention of leaders, } \\
\text { assessment, innovation of } \\
\text { teacher, student management, } \\
\text { teaching style, teaching plan, } \\
\text { practice teaching }\end{array}$ \\
\hline & & $\begin{array}{l}\text { home } \\
\text { education }\end{array}$ & $\begin{array}{l}\text { home culture, study habit, } \\
\text { mental and physical health }\end{array}$ \\
\hline & \multirow[b]{2}{*}{$\begin{array}{l}\text { Surround- } \\
\text { ings }\end{array}$} & $\begin{array}{l}\text { campus } \\
\text { culture }\end{array}$ & $\begin{array}{l}\text { campus culture construction, } \\
\text { school spirit, study style, } \\
\text { information diversity }\end{array}$ \\
\hline & & $\begin{array}{l}\text { innovation } \\
\text { atmosphere }\end{array}$ & $\begin{array}{l}\text { academic atmosphere, } \\
\text { academic level, academic } \\
\text { exchange, creating an } \\
\text { atmosphere of innovation, } \\
\text { innovation incentive, academic } \\
\text { competition, flexible study } \\
\text { time }\end{array}$ \\
\hline \multirow{4}{*}{$\begin{array}{l}\text { Internal } \\
\text { factors }\end{array}$} & \multicolumn{2}{|c|}{ intelligence } & $\begin{array}{l}\text { mode of thinking, level of } \\
\text { intelligence, insight, } \\
\text { imagination }\end{array}$ \\
\hline & \multicolumn{2}{|c|}{ knowledge } & $\begin{array}{l}\text { knowledge structure, learning } \\
\text { ability, information processing } \\
\text { ability, knowledge } \\
\text { accumulation, diversity of } \\
\text { experience, integration } \\
\text { capability, research ability }\end{array}$ \\
\hline & \multicolumn{2}{|c|}{ personality } & $\begin{array}{l}\text { emotion quotient (EQ), } \\
\text { volitional quality, challenge, } \\
\text { interest, teamwork, curiosity, } \\
\text { adventure, feeling of urgency, } \\
\text { introversion, extroversion }\end{array}$ \\
\hline & \multicolumn{2}{|c|}{ motivation } & $\begin{array}{l}\text { academic attitude, questioning } \\
\text { spirit, self-management, } \\
\text { independency learning, self- } \\
\text { confidence, activeness, sense } \\
\text { of competition }\end{array}$ \\
\hline
\end{tabular}

\section{Analysis of influence factors of creativity development}

\section{1) External factors}

External factors include society, education, surroundings. The three main influence factors not only can promote the development of creativity while restrict the development of creativity.

\section{a) Society factor}

The mainstream sense of worth of society plays a more important role for the influence of creativity development. Nowadays, a lot of universities still use final examinations to test the student's ability, which leads to students like a unified learning model, and students always wait for teacher to help them review the knowledge what they have learned in the class. When the students faced the problem that they can't solve, the first thing what they think about is that they need to the teacher's help. The students gradually lose their creativity.

Public opinion can influence the creativity development of the people. If people think the man who has creativity is a strange person, the creativity of the man would be affected obviously. On the contrary, if people always encourage the man who has creativity, they will be more willing to develop their creativity.

Personal relations are one of social influence factor. Good friendship promotes good emotional experience and affects the learning of individual creative methods and skills, thereby promotes positive thinking and creativity.

\section{b) Education factor}

As we have analyzed above, creative training in higher education is similar with applied undergraduate. Higher education directly affects the students' thinking, affects creativity development accordingly. University is the main base to cultivate the creativity of students. The quality of higher education determines whether the students can meet the needs of the development of the state and society. This requires higher education to carry out a comprehensive reform, the management system and operation mechanism, the construction of modern university system, innovative talent training mechanism, establish science and technology innovation system in Colleges and universities, personnel system, building a creativity development training education system.

Home education has fostered children's character and habits, and helps children to develop their personal potential. Many parents often make their children inferiority and lack of confidence in China, for example, parents always say that someone has good grades rather than their own children, but confidence is an important prerequisite for exploring and innovating.

\section{c) Surroundings factor}

Through the rich campus culture life, we can broaden students' knowledge, adjust their knowledge structure, and enable students to give full play to their imagination and creativity. We should encourage students to participate in extracurricular scientific and technological innovation activities 
and social practice activities and enrich students' amateur cultural life[5].

Creativity development is inseparable from innovation atmosphere. To create a good campus culture atmosphere, make students' management ability, social ability, independent ability, innovation ability and affective factors play in different extent, maximize the individual innovation potential, so as to compensate for the lack of school daily teaching content.

\section{2) Internal factors}

Internal factors include intelligence, knowledge, personality and motivation.

\section{a) Intelligence factor}

Intelligence is the foundation of creativity. Intelligence plays three key roles in creativity: synthesis, analysis and practice. We need to use our intelligence to see the processing of information and look at problems in a new perspective. The mode of thinking determines the way of creation. People's thinking mode can't only promote creativity development, but also impede creativity development. Once a person is good at looking at problems in a new perspective, he has formed a preference for solving problems, he will have a fixed thinking mode, and it is difficult to solve the problem in a new thinking mode.

\section{b) Knowledge factor}

Knowledge is the wing of creativity. If you want to be creative, you need to know a certain amount of knowledge. It is a very foolish action to blindly study and spend unnecessary time and energy without certain knowledge. Therefore, if you want to develop your creativity, you need to master enough knowledge first.

\section{c) Personality factor}

Personality also affects the development of creativity, and personality can be seen as a way of interacting with the environment. Someone's success is attributable to their own personality. They have strong volitional quality and can withstand huge setbacks. With the lack of strong volitional quality, one's creativity is difficult to present.

\section{d) Motivation factor}

Motivation is the driving force of creativity. To be creative, you need to have clear motivation and goal. Motivation is important for creative work, because it makes the individual go all out.

\section{CONCLUSIONS}

Creativity is one of the most core characteristics of talent, creativity development of students are top priorities for higher education. More and more universities pay more attention to how to cultivate the student's creativity development, we analyze the current situation of applied undergraduate about creativity development education, the basic data from papers and questionnaires of applied undergraduate, and conclude the important influence factors of creativity development of applied undergraduate based on knowledge mining technology, and we divided these factors into two types influence factors: external factors and internal factors. External factors include society, education, and surroundings, internal factors include intelligence influence, knowledge, personality, and motivation and so on, then we analyze these factors one by one. These important factors have important guiding significance to the training methods, education and teaching of creativity development for undergraduate, especially applied undergraduate. We will further study what is the key influence factor of creativity development from these influence factors.

\section{ACKNOWLEDGMENT}

The authors want to thank the helpful comments and suggestions from the anonymous reviewers.

\section{REFERENCES}

[1] Li Xiang, "Exploration and practice of the training mode of applied software technology talents", Computer education, 2007,vol.15, pp.7274.

[2] LI Shi-chun, et al., "Innovation Ability Comprehensive Quality Cultivation of Applied Talent in Newly-built University”, Value Engineering, 2013, vol.2, pp.199-201.

[3] Guilford, J.P, “Creativity”. American Psychologist, 1950, vol.5, pp.444454.

[4] Amabile, T.M., "Motivating Creativity in Organizations: On Doing What You Love and Loving What You Do", California Management Review, Berkeley, 1997, vol. 40(1), pp. 20-39.

[5] WANG Ying, "Research on Applied Innovative Training Problem and Suggestion”, Theory and Practice of Education, 2016, vol.36 (36), pp.12-14. 